\title{
At Variance with the Administrative Exemption Procedures of ERISA: A Proposed Reform
}

In 1974 employee benefit plans ${ }^{1}$ in the United States provided retirement and other benefits to almost half of the nonagricultural work force in the private sector and had accumulated an estimated $\$ 175$ billion in assets, ${ }^{2}$ one of the largest accumulations of investment capital in our economy. The need for more effective control of pension plan fiduciaries was one of the reasons Congress enacted the Employee Retirement Income Security Act of 1974 (ERISA). ${ }^{3}$ Among the fiduciary provisions of the Act are "Prohibited Transactions Rules" (Rules) that proscribe certain classes of transactions where there exists a significant potential for fiduciary abuse. ${ }^{4}$ Because many transactions fall within the Rules yet offer no opportunity for insider misconduct and, indeed,

1. As used in this Note, the terms "employee benefit plan," "pension plan," or "plan" will refer to the definition of "employee benefit plan" contained in the Employee Retirement Income Security Act of 1974 (ERISA). An "employee benefit plan" means either an employee welfare benefit plan or an employee pension benefit plan. ERISA $\$ 3(3), 29$ U.S.C. $\$ 1002(3)$ (Supp. V 1975). The former encompasses any plan providing medical, surgical, and hospital benefits, payment in the event of sickness, accident, disability, death, or unemployment, and even plans providing vacation pay, apprenticeship programs or scholarship funds, and day care and prepaid legal services. Id. $\$ 3(1), 29$ U.S.C. $\$ 1002(1)$ (Supp. V 1975). The latter includes plans providing retirement income and deferred compensation to employees. Id. $\$ 3(2), 29$ U.S.C. \$ 1002(2) (Supp. V 1975).

2. D. McGill, Fundamentals of Private Pensions 29 (1975); see S. Rep. No. 127, 93d Cong., lst Sess. 3 (1973), reprinted in [1974] U.S. Code CoNG. \& AD. Ncws 4839-40 (in 1973, 30 million workers or over half industrial work force in United States covered by private pension plans) [hereinafter cited as SENATE REPORT, with page citation to [1974] U.S. Code Cong. \& Ad. News].

3. Pub. L. No. 93-406, 88 Stat. 829 (1974) (codified principally at 29 U.S.C. $\$ \$ 1001-1381$ (Supp. V 1975) and in scattered sections of the Internal Revenue Code). The Act's legislative history is contained in [1974] U.S. Code CoNG. \& AD. News 4639-5190. For an overview of ERISA, see Comment, The Employee Retirement Income Security Act of 1974: Policies and Problems, 26 Syracuse L. Rev. 539 (1975). A more detailed discussion of the Act's section entitled "Fiduciary Responsibility" is articulated in Note, Fiduciary Standards Under the Employee Retirement Income Security Act of 1974, 63 GEo. L.J. 1109 (1975).

4. ERISA $\S \S 406,407(a), 29$ U.S.C. $\$ \S 1106,1107$ (a) (Supp. V 1975). The Prohibited Transactions Rules impose three types of proscriptions upon plan fiduciaries: (a) a fiduciary shall not cause the plan to engage in a transaction, such as a sale of property, extension of credit, or furnishing of services, with a party-in-interest; (b) a fiduciary shall not deal with plan assets for his own account or act contrary to interests of the plan; and (c) a fiduciary shall not allow the plan to purchase or hold employer real property or securities if such holdings constitute more than $10 \%$ of the plan's assets. See pp. 766-67 \& notes 34-37 infra.

The tax provisions of ERISA (Title II) contain similar proscriptions. ERISA $\$ 2003(a)$, I.R.C. $\$ 4975$ (c)(1). This Note, however, will deal primarily with the labor provisions of the Act (Title I). 
confer benefits upon plan participants, ${ }^{5}$ the Act provides for administrative variances and other exemptions from the absolute proscriptions of the Rules. ${ }^{6}$

This Note both argues that the administrative variances have not worked effectively and proposes certain reforms. It first analyzes the Rules in light of the background of ERISA, the Act's fiduciary responsibility provisions, and the specific costs of the Rules. The Note then examines the administrative variances and finds them inadequate because of lengthy procedures and an overprotective, complex standard. Finally, the Note proposes that Congress mandate a streamlined agency procedure and an "objective fairness" test for processing variance applications. The proposed procedures and standards would accelerate the variance process, curtail the costs of the Rules, and yet provide an effective, though diminished, level of protection against fiduciary abuse.

\section{ERISA's Regulation of Fiduciary Abuse: Prohibited Transactions Rules}

Because substantial capital funds held in private pension plans are essential sources of individual retirement security, ${ }^{7}$ fiduciary regulation is necessary. ERISA's disclosure requirements and fiduciary standards are beneficial in policing insider misconduct. But the Rules impose costs not justified by the extra protection afforded.

5. See pp. 767-69 \& notes 38-50 infra.

6. See ERISA $\$ 408(a), 29$ U.S.C. $\$ 1108$ (a) (Supp. V 1975). An administrative exemption or variance may exempt a transaction, proscribed under $i d . \$ 406,29$ U.S. $\$ 1106$ (Supp. $V$ 1975), from the prohibitions of the Rules. A variance can only be granted after application to, and approval by, both the Secretary of Labor and the Commissioner of Internal Revenue. All prohibited transactions exemption applications are available for public inspection at the Public Documents Room of Pension and Welfare Benefits Programs, Room N.4677, U.S. Dep't of Labor, 200 Constitution Avenue, N.W., Washington, D.C. Several of the applications and accompanying agency responses are discussed in this Note. These applications will be cited with their initial filing date as follows: "Application No. C-777, Mar. 13, 1975." Prohibited Transactions Exemptions granted by the agencies will be cited, for example, as "PTE 78-3," with appropriate citation to the location in the Federal Register at which they appear.

Other exemptions include transitional rules, ERISA $\$ 414,29$ U.S.C. $\$ 1114$ (Supp. V 1975), and statutory exemptions, id. $\$ 408(b), 29$ U.S.C. $\$ 1108$ (b) (Supp. V 1975). Transitional rules exempt otherwise prohibited transactions for an interim period, and statutory exemptions include those transactions falling within their narrow and specific terms and conditions.

7. E. Allen, J. Melone \& J. Rosenbloom, Pension Planning 2, 7 (3d ed. 1976) ("problem of economic security ... is a serious and increasingly important problem"; assets of private pensions currently $\$ 180$ billion and growing at average rate of $\$ 14$ billion a year). See p. 760 \& note 2 supra. 


\section{A. Background: Need for Federal Regulation of Pension Fiduciaries}

Private pension plans generally are sponsored-that is, established and funded-by unions or employers for the benefit of employees. ${ }^{8}$ In certain cases the management of plan assets may be affected by a symbiotic relationship between the pension plan and its sponsors. ${ }^{9} \mathrm{Al}-$ though such a relationship may benefit both the plan and its sponsors, ${ }^{10}$ union or employer control over plan management and investment creates conflicts of interest and opportunities for abuse. One major conflict-of-interest situation is the temptation to invest part of the plan's assets in the sponsor's own stock or other property. ${ }^{11}$ Other potentially abusive situations exist where a sponsor makes an unsecured loan to himself or where the sponsor, as trustee, pays himself an exorbitant salary for occupying a sinecure, such as "financial manager" or "consultant."12

Although the need for regulation of such a naturally problematic area seems obvious, comprehensive federal regulation of pension fiduciaries did not exist until the enactment of ERISA in $1974 . .^{13}$ Congress finally acted for two reasons: instances of serious fiduciary abuses in plan management came to light in the 1960s and early 1970s, and the legal remedies for such practices proved totally ineffective. ${ }^{14}$

8. See Note, Pension Plans and the Rights of the Retired Worker, 70 Conum. L. Rev. 909,909 (1970) (pension plans most frequently take form of trust where employer acts as grantor or creator). For a short description of the basic features and functions associated with private pension plans, see E. Allen, J. Melone \& J. Rosenbloom, supra note 7, at 20-65; D. MCGILL, supra note 2, at 58-73.

9. See Senate RePort, supra note 2, at 4869 ("[S]uch an employer will often be an administrator of his plan, or will function as a trustee or in some other fiduciary capacity .... [It is recognized that there is a] symbiotic relationship existing between the employer and the plan covering his employees.")

10. The symbiosis of plans and contributors may directly benefit plans in three ways: (1) elimination of transactions costs; (2) provision of unique services or goods that are unavailable in the marketplace; and (3) provision of especially favorable terms that are sometimes given to a plan by its sponsor. See pp. 767-69 \& notes $38-48$ infra.

11. J. Brooks, Conflicts of Interest: Corporate Pension fund Asset Management 13 (1975).

12. See Private Welfare and Pension Plan Legislation: Hearings on H.R. 1045, H.R. 1046 \& H.R. 16462 Before the House General Subcomm. on Labor, 91st Cong., 1st \& 2d Sess. 470-72 (1969-70) (appendix to statement of George Shultz, Sec'y of Labor) [hereinafter cited as House Hearings].

13. SENATE REPORT, supra note 2, at 4840 (prior to ERISA, private pension plans constituted "the only large private accumulation of funds which have escaped the imprimatur of effective federal regulation"); D. McGILL, supra note 2, at 29 (assets of private pension plans subject to only peripheral regulation prior to 1974).

14. See S. REP. No. 383, 93d Cong., 1st Sess. 3 (1973), reprinted in [1974] U.S. Code Cong. \& AD. NEws 4892 (cases discovered of "extreme misuse of pension funds"; instances where funds not managed for best interests of covered employees); SENATE RErorT, supra note 2, at 4840-42 (describing deficiencies in federal laws designed to regulate fiduciary responsibility). 
The most blatant of the pension fund scandals that focused congressional attention on the need for reform involved the Teamsters' Pension Fund. Investigations in 1969 revealed that Fund managers had channeled millions of dollars into loans, usually unsecured and at no interest, to support suspicious operations and "Mob cronies" of Teamster officials. ${ }^{15}$ These revelations stimulated interest in legislation that had been introduced in 1967 to effect "[a] major overhaul of laws governing private pension plans which would prevent abuses such as 'conflicts of interest, kickbacks and payroll padding." "16 Further scandals were uncovered in 1971: the United Mine Workers' Welfare and Retirement Fund had been defrauded of millions of dollars deposited in a union-controlled bank at no interest, ${ }^{17}$ and the Penn Central's Fund held a million dollars in the Railroad's valueless stock. ${ }^{18}$ Other, less dramatic, abuses came to light in the congressional hearings on pension reform: exorbitant fees charged funds by trustees and administrators, excessive bank deposits, stock manipulations, imprudent investment, excessive administrative costs, bribery, and embezzlement. ${ }^{19}$ By passing ERISA, Congress sought to prevent recurrence of such fiduciary abuses. Although Congress recognized that "the magnitude of these improper practices is small in relation to the total number of plans in existence," it nonetheless concluded that "the seriousness of the improper practices disclosed indicates the need for additional precautions to insure that these specific examples do not become general conditions."20

Prior to ERISA, two federal statutes required disclosure of pension

15. House Hearings, supra note 12 , at $120-42$ (describing gross mismanagement of $\$ 628$ million Teamsters' Central States, Southeast and Southwest Areas Pension Fund).

16. Id. at 142 (bill introduced by Sen. Javits, which addresses problems of vesting and fiduciary abuse). The pension reform movement that culminated in the passage of ERISA began in March 1962, when President Kennedy appointed a Cabinet Committee on Corporate Pension Funds to conduct an investigation and assessment of laws that governed private pension and other employee retirement income programs. This Committee reported its finding to President Johnson on January 15, 1965. See Public Policy and Private Pension Programs: A Report to the President on Private Employee Retirement Plans (1965).

17. J. Brooks, supra note 11, at 5. Cf. Blankenship v. Boyle, 329 F. Supp. 1089 (D.D.C. 1971) (breaches of trust whereby trustees of United Mine Workers' Welfare and Retirement Fund engaged in widespread mismanagement, placed themselves in situations where their loyalties conflicted, and fraudulently manipulated funds through union-controlled bank).

18. J. Brooks, supra note 11 , at 6.

19. See generally House Hearings, supra note 12, at 470-72 (appendix to statement of George Shultz, Sec'y of Labor) (examples of stock manipulations, exorbitant fees charged by plan trustees, and excessive bank deposits).

20. H.R. REP. No. 533, 93d Cong., lst Sess. 13 (1973), reprinted in [1974] U.S. CoDE CoNG. \& AD. News 4651 [hereinafter cited as House REPORT, with page citation to [1974] U.S. Code CONG. \& AD. NEWs]. 
plan information to the Department of Labor. ${ }^{21}$ It was expected that this information would enable plan beneficiaries to police fiduciary abuse by bringing civil suits; participants failed to sue, however, in part because they found it difficult to obtain information relating to their plans. ${ }^{22}$ Moreover, Congress learned that "an average plan participant, even where he has been furnished an explanation of his plan provisions, often cannot comprehend them because of the technicalities and complexities of the language used." 23 When beneficiaries did bring suits, they were forced to rely on the common law of trusts, since the federal statutes contained no substantive standards of conduct. ${ }^{24}$ These suits were generally unsuccessful, primarily because of judicial deference to exculpatory clauses in trust indentures. ${ }^{25}$ The other regulatory scheme available against fiduciary misconduct-the In-

21. Welfare and Pension Plans Disclosure Act of 1958 (WPPDA), 29 U.S.C. $\$$ 301-309 (1970) (repealed in 1975 by ERISA $\$ 111(\mathrm{a})(1), 29$ U.S.C. $\$ 1031$ (a)(1) (Supp. V 1975)) (requiring fiduciary to prepare and file description and annual report of plan); LaborManagement Reporting and Disclosure Act of 1959 (LMRDA), 29 U.S.C. $\$ 432$ (1970) (requiring union officials and all others who came into contact with union plan to file report disclosing six conflict of interest situations).

For a complete description of pre-ERISA federal laws affecting the administration of private pension plans, see Interim Report of The Private Welfare and Pension Plan Study, S. Rep. No. 634, 92d Cong., 2d Sess. (1971). For an analysis of both federal and state regulations, see B. Aaron, Legal Status of Employee Benefit Rights under Private Pension Plans 90-117 (1961); E. Patterson, Legal Protection of Private Pension ExPECTATIONS 85-113, 188-215 (1960).

22. House REPORT, supra note 20, at 4642 (experience demonstrated inadequacy of WPPDA; weaknesses were its limited disclosure requirements and reliance on initiative of participants to police management of plan); $c f$. Landau, Merholtz \&: Perkins, Protecling a Potential Pensioner's Pension-An Overview Of Present And Proposed Law On Trustees' Fiduciary Obligations and Vesting, 40 BROOKLYN L. REv. 521, 547 (1974) (problem with WPPDA was it "relie[d] on the individual employees and beneficiaries, through their perusal of annual reports, to compel the trustees and administrators to comply with the Act's provisions," which failed as enforcement method "because of the self-defeating complexity of annual reports and other relevant data").

23. SENATE REPORT, supra note 2, at 4847.

24. House REPORT, supra note 20, at 4642 (WPPDA was "wholly lacking in substantive fiduciary standards"); Note, supra note 3, at 1110 (LMRDA imposes fiduciary duties on union officials, but offers "no protection to most pension plan beneficiaries").

Traditional trust law imposes upon fiduciaries a duty of individual loyalty that prohibits various forms of self dealing, including the purchase of trust property, use of the trust property for the trustees' own purposes, and competition with the beneficiary. RESTATEMeNT (SECOND) of Trusts $\$ \$ 170-188$ (1959). See Committee of Trust Administration and Accounting, The Trustee's Duty of Loyalty, 6 REAL Prop., Prop. \&. Tr. J. 528 (1971).

25. See SENATE REPORT, supra note 2, at 4865 (courts in applying trust law to employec benefit plans have allowed settlor to use exculpatory clauses relieving himself from liability in certain instances even though plan "is quite different from the testamentary trust both in purpose and in nature"); E. PATTERSON, supra note 21, at 165 ("Exculpatory clauses are quite commonly inserted in pension-trust agrcements of trust companies and are, of course, equally effective as to individual trustees of pension funds"); Note, Proposed Amendments to the Welfare and Pension Plans Disclosure Act, 4 U. MICH. J.L. REF. 267, 278 (1970) (few participants have brought suits and in those instances when they have, courts have tended to construe provisions strictly). 
ternal Revenue Code-was even less useful. The only sanction available to the Service was to cut off all tax benefits to the plan, a move that unfairly penalized plan beneficiaries. ${ }^{26}$

\section{B. ERISA's Regulation of Pension Fiduciaries}

After finding serious abuses in pension plan management and ineffective legal controls, Congress sought to provide efficacious regulation through ERISA. The Act dramatically improves the disclosure provisions of prior federal law. Participants must be provided a summary of their plan "written in a manner calculated to be understood by the average plan participant." ${ }^{27}$ Moreover, sponsors must file more detailed accounts of fund investments in annual reports to the Department of Labor. ${ }^{28}$

ERISA also establishes stringent standards for fiduciary responsibility and stiff penalties for their violation, enforceable both by participants and by the Department of Labor. ${ }^{20}$ The overriding fiduciary rule is the "prudent expert" standard: each fiduciary must discharge his duties "with the care, skill, prudence, and diligence under the circumstances then prevailing that a prudent man acting in a like capacity and

26. I.R.C. $\$ 401$ (permitting deduction by employer for contributions made to qualified employee trust); id. $\$ \$ 401(a)$, 503(a), (b) (plan "qualified" only if managed for exclusive benefit of employees and plan did not engage in certain prohibited transactions, includ. ing loan at unreasonable rate of interest, payment of excessive compensation for personal services, purchases of property for more than adequate consideration). See STAFF of SENATE Comm. on Labor and Public Welfare, 94tu Cong., 2d Sess., Legislative History of ERISA: Public Law 93-406, at 1071 (Comm. Print 1976).

The Code might have been an effective regulatory scheme, but the "possible loss to innocent employees has caused the Service to be reluctant to impose the sanctions." $S$. Rep. No. 383, supra note 14, at 4978. Cf. Sevate Report, supra note 2, at 4841 (Code ineffective in policing fiduciary misconduct because "its primary functions are designed to produce revenue and to prevent evasion of tax obligations").

27. ERISA $\$ 102(a)(1), 29$ U.S.C. $\$ 1022(a)(1)$ (Supp. V 1975).

28. Id. $\$ 103$, 29 U.S.C. $\$ 1023$ (Supp. V 1975).

29. Under the labor provisions, a fiduciary who breaches the fiduciary requirements of the Act is personally liable for any losses to the plan resulting from the breach and for restoring to the plan any profits. Other relief, including removal, is available as a court should deem appropriate. Id. $\$ 409,29$ U.S.C. $\$ 1109$ (Supp. V 1975). The Secretary of Labor may assess a civil penalty against a party-in-interest involved in a prohibited transaction, and a civil action may be brought by a participant, beneficiary, or the Secretary to enforce the provisions of the Act and for any other appropriate relief. Id. $\$ 502,29$ U.S.C. $\$ 1132$ (Supp. V 1975). Criminal penalties of imprisonment of one year and a $\$ 5,000$ fine may be imposed on any individual willfully violating any provision in Title I. Id. $\$ 501,29$ U.S.C. $\$ 1131$ (Supp. V 1975). The "fiduciaries" regulated by the labor provisions embrace a wide range of individuals including officers and directors of a plan, members of a plan's investment committee, and persons who select these individuals. $I d . \$ 3(21)(\mathrm{A})$, 29 U.S.C. $\S 1002(21)$ (A) (Supp. V 1975).

Under the tax provisions of the Act (Title II), excise taxes are imposed on those "disqualified persons" guilty of engaging in a prohibited transaction. Id. $\$ 2003(\mathrm{a})$, I.R.C. $\S 4975(\mathrm{a})$, (b). 
familiar with such matters would use in the conduct of an enterprise of a like character and with like aims." 30 In addition to this central principle, section 404 of the Act further mandates that a fiduciary discharge his duties solely in the interests of the participants and for the exclusive purpose of providing benefits to the plan. ${ }^{31}$ Finally, ERISA proscribes certain classes of transactions between interested parties and plans; ${ }^{32}$ the understanding of Congress was that these "proscriptions ... represent the most serious type of fiduciary misconduct which in one way or another has occurred in connection with some welfare or pension plans." 33

Specifically, the Rules focus on three types of transactions. First, a fiduciary may not cause a plan to engage in certain transactions with a "party-in-interest," such as the "lending of money or other extension of credit." 34 The Act defines "party-in-interest" very broadly to include any administrator, officer, trustee, custodian, counsel, or employee of a plan, any fiduciary, any person providing services to a plan, the employer of covered employees, as well as certain relatives of these individuals. ${ }^{35}$ Second, a fiduciary may not deal with the assets of the plan for his own account, act on behalf of an individual whose interests are adverse to the interests of the plan, or receive any compensation for his personal account from any party dealing with the plan. ${ }^{36}$ Finally, the pension fund may not acquire or possess securities of the

30. Id. \$ 404(a)(1)(B), 29 U.S.C. \$ 1104(a)(1)(B) (Supp. V 1975). See Williams, The Prudent Man Rule of the Pension Reform Act of 1974, 31 Bus. LAw. 99 (1975); Note, Fiduciary Standards and the Prudent Man Rule Under the Employment [sic] Retirement Income Security Act of 1974, 88 HARV. L. REv. 960 (1975). The Act's standard differs from the traditional "prudent man" rule in assuming expertise in administering and investing plan assets, thus prompting the label "prudent expert" rule. See Cummings, Purposes and Scope of Fiduciary Provisions under the Employee Retirement Income Security Act of 1974, 31 Bus. LAw. 15, 35 (1975).

31. ERISA $\S 404(a)(1)(A), 29$ U.S.C. $§ 1104(a)(1)(A)$ (Supp. V 1975). Although this "exclusive purpose" rule essentially imposes the traditional duty of loyalty upon a fiduciary, the principal problem with applying trust law to employee benefit plans has been eliminated. Under the Act, any provision relieving a fiduciary of liability is prohibited. Id. $\S 410$ (a), 29 U.S.C. $\$ 1110$ (a) (Supp. V 1975).

Another requirement is that the fiduciary diversify the investments of the plan. Id. $\S 404(\mathrm{a})(1)(\mathrm{C}), 29$ U.S.C. $\$ 1104(\mathrm{a})(1)(\mathrm{C})$ (Supp. V 1975). To comply with this rule, a fiduciary should not invest the whole or an unreasonably large portion of the trust property in a single security or in various types of securities dependent on the success of one enterprise or on conditions in one locality. H.R. REP. No. 1280, 93d Cong., 2d Sess. 304 (1974), reprinted in [1974] U.S. CoDE CoNG. \& AD. News 5085 [hereinafter cited as Conference Report, with page citations to [1974] U.S. Code Cong. \& AD. News].

32. ERISA $\$ \S 406,407$ (a), 29 U.S.C. $\$ \S 1106,1107$ (a) (Supp. V 1975). See note 4 supra.

33. House REPORT, supra note 20 , at 4651 .

34. ERISA $\S 406(a)(1)(B), 29$ U.S.C. $\$ 1106(a)(1)(B)$ (Supp. V 1975).

35. Id. $\$ 3(14), 29$ U.S.C. $\$ 1002(14)$ (Supp. V 1975).

36. Id. $\S 406(\mathrm{~b}), 29$ U.S.C. $\S 1106(\mathrm{~b})$ (Supp. V 1975). 
employer or real property leased to the employer except in limited circumstances. $^{37}$

\section{Prohibited Transactions Rules: Costs}

The main benefit of the Prohibited Transactions Rules is added protection against fiduciary abuse: if classes of transactions, some of which are inherently susceptible to abuse, are forbidden, then plans should incur fewer losses due to insider misconduct. Without an efficiently functioning exemption mechanism, however, the operation of the Rules may result in unnecessary costs to plans and their par: ticipants.

The Rules generate direct costs to plans by prohibiting transactions with interested parties even when plans would benefit. There are at least three situations in which the proscription of such transactions may impose costs on plans. First, a plan and a party-in-interest, frequently a contributing employer or union, often maintain a business relationship that permits the elimination of transactions costs. ${ }^{38}$ Such relationships were "permitted and were not uncommon" under prior law but are forbidden by the Rules. ${ }^{39}$ For example, the sponsor or its agents may be able to provide useful investment or management services to its pension fund and can conduct business with the plan at low cost. ${ }^{40}$ Indeed, where a transaction with a sponsor involves fair market terms, the plan will benefit to the extent it may incur less transactions costs. ${ }^{41}$

37. Id. $\$ \$ 406(a)(2), 407(a), 29$ U.S.C. $\$ \S 1106(a)(2), 1107(a)$ (Supp. V 1975) (plan may hold employer real property and securities if fair market value of such holdings does not exceed $10 \%$ of fair market value of plan).

38. See W'eiss \& Voboril, Fiduciary Standards And Investment Responsibility Under the New Pension Reform Law, 113 TR. \& EST. 800, 858-60 (1974) (detailing six types of transactions that "may be quite favorable to the plan primarily for one reason-that is, by aggressive and creative management the plan trustees have successfully eliminated the middleman").

39. Id. at 858-59 (among transactions permitted and common under prior law but prohibited under Rules are: sale of warehouse owned by sponsor to plan for adequate consideration when warehouse can be easily rented and is sound investment, prohibited under ERISA $\S 406(a)(1)(A), 29$ U.S.C. $\$ 1106(a)(1)(A)$ (Supp. V 1975); sponsor seeks to effect loan secured by first mortgage on real property at interest rate of $12 \%$ from its retirement plan, prohibited under ERISA $\$ 406(\mathrm{a})(1)(B), 29$ U.S.C. $\$ 1106(\mathrm{a})(1)(B)$ (Supp. V 1975)).

40. Neal \& Bret, ERISA limitations on the performance of "multiple services" by fiduciaries, $44 \mathrm{~J}$. TAx. 90, 90 (1976), note that "it may be effective cost-wise for plan to purchase actuarial consulting services, portfolio evaluating services, and trust accounting and auditing services from one organization." Nevertheless, such arrangements with a party-in-interest are prohibited under ERIS.A $\S 406(\mathrm{a})(\mathrm{I})(\mathrm{C}), 29$ U.S.C. $\S 1106(\mathrm{a})(\mathrm{I})(\mathrm{C})$ (Supp. V 1975) (prohibiting "furnishing of goods, services, or facilities between the plan and a party in interest").

41. See Application No. D-457, Apr. 1, 1976. The application involved a request by a moncy-purchase plan to sell land to a shareholder and trustec, a "party-in-interest" transac- 
Plans may also benefit when parties-in-interest provide multiple services. For example, Congress recognized the desirability of allowing brokerage houses to provide both investment management and brokerage services to the same plan. ${ }^{42}$

Added costs may also arise in situations where a party-in-interest is in a unique position to transact with its plan. ${ }^{43}$ For instance, a sponsor may save money for the pension fund by purchasing blocks of stock in situations in which the plan might be unable to find enough buyers or in which a large offering would risk depressing the market for the stock. ${ }^{44}$ In other instances, a sponsor may possess specific land or buildings needed by the plan. ${ }^{45}$

tion prohibited under ERISA $\$ 406(a)(1)(A), 29$ U.S.C. $\$ 1106(a)(1)(A)$ (Supp. V 1975). The purchase price was set at $\$ 56,500$, the fair market value as determined by an independent appraiser. The plan wished to sell to the interested party so as to "avoid paying the expense of a real estate brokerage commission out of the proceeds of the sale." Nevertheless, this variance request was denied. Application No. D-609, Sept. 27, 1976 (on file with Yale Law Journal), requested that a profit-sharing trust be permitted to sell an antique automobile that it held for investment purposes to a "party-in-interest," a transaction prohibited under ERISA $\$ 406(a)(1)(A), 29$ U.S.C. $\$ 1106(a)(1)(A)$ (Supp. V 1975). The purchase price of $\$ 65,000$ was the fair market value as determined by two independent appraisers. Although the proposed transaction would alleviate the "short" cash position of the plan, allow the plan to realize a significant return on its investment (the automobile was purchased four years earlier for $\$ 40,000)$, and save the plan the expense of finding other buyers in a market where buyers are not readily available, the request for a variance was denied.

42. Conference RePORT, supra note 31 , at 5089-90 (although brokerage houses generally would be prohibited from providing both discretionary investment management and brokerage services to same plan, conferees expected that variances would be granted).

43. Such costs obtain because perfect substitutes are not available in the marketplace. Thus the proscription of a secured loan at the going market rate from a plan to a party-in-interest may impose costs on the plan to the extent other borrowers are unavailable and funds remain uninvested. See, e.g., Erlenborn, Problems in Pension Plan Regulation, 27 LAB. L.J. 195, 197 (1976) (Department of Labor and Internal Revenue Service effectively denied exemption application for loan from plan to party-in-interest; thus "pension fund must find another borrower while the funds remain uninvested"). Application No. D-198, June 23, 1975 (on file with Yale Law Journal), involved a request by a profit-sharing plan to purchase from the employer loans made by the employer to his customers, a transaction prohibited under ERISA $\$ 406(\mathrm{a})(1)(A), 29$ U.S.C. $\$ 1106(\mathrm{a})(1)(A)$ (Supp. V 1975). This "unique investment opportunity" had been utilized by the plan for the past 15 years and had shown an average return of $8.75 \%$. Because the plan was not in the business of making loans and the start-up costs for such an operation were prohibitive, the only means by which the plan could so invest its funds was through this prohibited transaction. Nevertheless, the variance request was denied.

44. See, e.g., 41 Fed. Reg. 29,503 (1976) (notice of pendency of exemption for proposed sale by Univar Retirement Plan of its holdings of common stock of Univar Corporation, plan's sponsor, to that corporation). In this transaction, the sponsor offered to repurchase the plan's entire block of company stock, because sale of the stock in the open market may have depressed the market price. An exemption was granted for this sale between the plan and a party-in-interest (prohibited under ERISA $\$ 406(\mathrm{a})(\mathrm{I})(\mathrm{A}), 29$ U.S.C. $\$ 1106(\mathrm{a})(\mathrm{I})(\mathrm{A})$ (Supp. V 1975)). See PTE 76-6, 41 Fed. Reg. 46,799 (1976).

45. See, e.g., 41 Fed. Reg. 56,412 (1976) (notice of pendency of exemption for proposed purchase by Iron Workers Apprentice Fund of tract of land owned by sponsoring union). 
Third, the Rules may impose costs on plans by precluding transactions between a contributing employer or union and a plan in which the sponsor demands something less than marketplace terms. ${ }^{46} \mathrm{Ex}$ amples are situations in which plan sponsors give interest-free loans or other short-term benefits to help plans in emergency situations. ${ }^{47}$ Plan sponsors may be willing to engage in such "uneconomic" behavior because they may consider pension plans to be crucial elements in the overall compensation of workers or because they may have "sunk costs" in plans. ${ }^{48}$

In addition to imposing costs in these situations, the Rules may harm plans in another respect. The inflexibility of the Rules and the expansive definition of "party-in-interest" may disrupt longstanding business arrangements among contributing employers and unions, plans, and other financial institutions. ${ }^{49}$ Such disruptions generate indirect costs to plans to the extent that they deter sponsor commitments to plans. .00

The Fund in this case desired to increase its parking facilities, and the only available land was that owned by the union, which agreed to sell for $\$ 24,859$; the appraised value was $\$ 28,300$. An exemption was granted for this sale (prohibited under ERISA $\$ 406(a)(1)(A)$, 29 U.S.C. $\$ 1106(a)(1)(A)$ (Supp. V 1975)). See PTE 77-2, 42 Fed. Reg. 13,633 (1977).

46. See Application No. D-247, July 28, 1975 (on file with Yale Law Journal). This application requested that $a$ bank pension plan be permitted to purchase certain real estate loans from the sponsoring bank, a transaction prohibited under ERIS. $\$$ 406(a)(1)(A), 29 U.S.C. $\$ 1106(a)(1)(A)$ (Supp. V 1975). Transactions identical to the one at issue had been engaged in by the parties for the past 14 years and had called for sale of only those loans that were of the highest quality and adequately secured. Further, the bank had arranged to repurchase any loan that, at any time, became delinquent. Despite the latter provision, which probably goes beyond the scope of arm's length business dealings, the variance request was denied.

47. See, e.g., 41 Fed. Reg. 15,481 (1976) (notice of pendency of exemption for proposed interest-free loan from sponsoring union to the Electrical Workers Union plan). The plan was unable to make payments on a health insurance policy for its members. The sponsor was willing to make the loan for an indefinite period, and the terms called for the trustee to repay only when the plan possessed sufficient liquidity. An exemption was granted for this loan between a party-in-interest and a plan (prohibited under ERISA $\$ 406(\mathrm{a})(\mathrm{I})(\mathrm{B})$, 29 U.S.C. $\$ 1106(a)(1)(B)$ (Supp. V 1975)). See PTE 76-5, 41 Fed. Reg. 30,414 (1976).

48. E. Allen, J. Melone \& J. Rosenbloom, supra note 7 , at 12 (employers who do not have pension plan are at "competitive disadvantage in attracting and holding personnel").

49. See Gerard \& Schreiber, ERISA: Prohibitions and Exemptions-Sections 406 and 40S, 21 N.Y.L.F. 385, 386 (1976) (Rules "encompass an extraordinary number of ordinary and otherwise perfectly proper transactions"); Comment, supra note 3, at 654 ("the broad range of activities which [the Rules] proscribed would interfere with the most common, and honest, of business practices"). See also General Oversight on ERISA: Hearing Before the Subcomm. on Labor Standards of the House Comm. on Education and Labor, 94th Cong., 2d Sess. 14-46 (1976) (examples of 37 types of transactions normally engaged in by multiemployer plans that are prohibited under Rules) [hereinafter cited as General Oversight Hearings].

50. There is evidence that the effect of ERISA's requirements, including the Prohibited Transactions Rules, is to "stall 25 years of steady growth" in private pension plans. PEN- 


\section{ERISA's Variances: Unsuccessful Palliatives}

In enacting the Prohibited Transactions Rules, Congress did not intend to establish a scheme that regulated fiduciary abuse at any cost. ${ }^{51}$ ERISA, therefore, provides that certain transactions are exempted from the operation of the Rules. Although administrative variances are a central means of exemption, they have not been processed in a timely and efficient manner. These exemptions thus have failed to reduce the costs of the Rules. As a consequence, legislation that would repeal the party-in-interest provisions of the Rules has been proposed in Congress. ${ }^{52}$

\section{A. The Provisions for Exemption}

The Act provides for three types of exemptions: transitional rules, class exemptions articulated in the statute (statutory exemptions), and administrative exemptions or variances. ${ }^{53}$ The transitional rules and the statutory exemptions, because they apply, respectively, for only limited periods and to specific types of transactions, are of limited significance in mitigating the costs of the Rules. ${ }^{54}$ The administrative

SION WoRLd, Mar. 1977, at 38 (Act's requirements prompted cancellation of 7,600 private pension plans in 1976 and brought $50 \%$ drop in number of new plans approved by Internal Revenue Service). The number of plan terminations in 1976 was a $100 \%$ increase over the comparable 1975 figure. Pension WorLd, Aug. 1976, at 3-4 (summarizing statement of Rep. Vanik, Chairman of House Subcommittee charged with ERISA oversight). A recent survey of pension plan actuaries revealed that a contributing factor in the increase in the number of plan terminatons is the cost of the Act's fiduciary responsibility requirements. PENSION WORLD, Jan. 1977, at 61 .

The reason for this detrimental effect upon plan particiants is the "voluntary" nature of pension commitments by sponsors. If the cost of restructuring business relationships is high, sponsors may simply stop contributing to plans. See Joint Oversight Hearing on the Employee Retirement Income Security Act of 1974, Joint Hearing Before the Subcomm. on Labor Standards of the House Comm. on Education and Labor and the Subcomm. on Oversight of the House Comm. on Ways and Means, 94th Cong., 1st Sess. 2 (1975) (careful and creative efforts must be made to accomplish objectives of pension reform while encouraging growth of both small and large plans) [hereinafter cited as Joint Oversight Hearing]; Comment, supra note 3 , at 555 (describing "dilemma" of voluntary pension system: "[a]s long as the private system remains voluntary in nature, the level of retirement income security provided will depend upon the willingness of employers to create plans").

51. See S. REP. No. 383, supra note 14 , at 4904 (committee has sought to adopt provisions that strike balance between providing meaningful reform and keeping costs within reasonable limits).

52. Subcomm. on Labor Standards of the House Comm. on Education and Labor, Amendment to the Employee Retirement Income Security Act of 1974, H.R. Rep. No. 646, 94th Cong., Ist Sess. (1975) (description of H.R. 7597, which would have repealed party-in-interest provisions of Rules and narrowed definition of "fiduciary") [hereinafter cited as House Amendment Report].

53. See note 6 supra.

54. The transitional rules were designed to prevent undue hardship to those affiliated with employee benefit plans who engaged in activities that were to be proscribed under ERISA but did not violate previously existing law. ERISA $\S 414,29$ U.S.C. $\$ 1114$ (Supp. $\mathrm{V}$ 1975). The statutory exemptions cover nine classes of transactions that would otherwise 
variances were instituted to ensure flexibility in the operation of the Prohibited Transactions Rules.

Section 408 of the Act details the decisional standards that are to be applied by the two agencies charged with the administration of the variances, the Department of Labor and the Internal Revenue Service. The agencies may not grant a variance unless it is determined that such exemption is "( 1 ) administratively feasible, (2) in the interests of the plan and of its participants and beneficiaries, and (3) protective of the rights of participants and beneficiaries of such plan."

The procedures involved in the disposition of a variance request are lengthy and complex, ${ }^{56}$ despite the congressional directive that the agencies coordinate policies and procedures in processing exemption applications. ${ }^{57}$ The administrative variance process is initiated by an interested party who normally files with the Internal Revenue Service and the Department of Labor an application that details all relevant information. ${ }^{58}$ The application is first reviewed by supervisory personnel from each agency who jointly assign primary and secondary agency responsibility ${ }^{59}$ The application is next analyzed by a "case initiator" 00 in the primary agency. The initiator assesses whether the exemption is "protective of the rights" of plan participants by determining whether the terms of the transaction are "adequate" or "reasonable." ${ }^{11} \mathrm{He}$ also considers whether the exemption is "in the

fall within the Rules. Among these are the provision by a party-in-interest of office space and services necessary to the establishment or operation of the plan, and the provision in certain circumstances of ancillary services by a bank or other financial institution when such party is a fiduciary. Id. $\$ 408(\mathrm{~b})(2),(6), 29$ U.S.C. $\$ 1108(\mathrm{~b})(2),(6)$ (Supp. V 1975). Under the statutory exemptions, the fiduciary need determine only that the proposed transaction fulfills the terms and conditions of one of the narrowly defined categories. For an example of the narrowness of the scope of the statutory exemptions, see the detailed conditions prescribed in the "participant loan" exemption, $i d . \$ 408(b)(1), 29$ U.S.C. $\$ 1108$ (b)(1) (Supp. V 1975).

55. Id. $\$ 408(a), 29$ U.S.C. $\$ 1108(a)$ (Supp. V 1975) (before granting exemption, Sec'y of Labor shall publish notice in Federal Register, give adequate notice to interested persons, and afford opportunity for presentation of views).

56. See Internal Revenue Service/Department of Labor-Memorandum of Understanding, [1976] 3 Pension \& Profit Sharing (P-H) I 120,090 (description of interagency procedures involved in processing exemption applications) [hereinafter cited as Memo of Understanding].

57. ERISA $\$ \S 408(a), 3003,3004,29$ U.S.C. $\$ \S 1108(a), 1203,1204$ (Supp. V 1975).

58. See ERISA Procedure 75-1, 40 Fed. Reg. 18,471 (1975) (detailing information to be submitted with application for exemption, including description of transaction and fiduciary, description of hardship or economic loss that would result to interested party, plan, and participants if exemption denied, explanation of fulfillment of statutory criteria, and statement whether notice of termination has been filed).

59. Memo of Understanding, supra note 56.

60. Id. (within Dep't of Labor: Case Employee Benefit Plan Specialist).

61. Interview of Case Employee Benefit Plan Specialist, Division of Exemptions, Variances and Determinations, Dep't of Labor. Nov. 28, 1977 (notes on file with Yale Law Journal) [hereinafter cited as Case Analyst Interview]. 
interests of the plan and of its participants" by making a determination of the necessity of the transaction, the availability of substitute transactions, and other factors indicating the "economic loss" that might be suffered by the plan. ${ }^{82}$

After the primary agency makes its decision, the secondary agency begins its review of the application and, after a separate examination of the facts, may accept or reject the prior determination. If the agency having secondary authority agrees that the statutory criteria have been met, ${ }^{63}$ notice is published in the Federal Register that an exemption is being considered. After notice, and review of all comments and testimony at any hearings, the primary agency determines whether to grant a variance. ${ }^{64}$

\section{B. Operation and Effect of ERISA's Administrative Exemptions}

ERISA's variance process has not operated satisfactorily. Although 825 requests for variances have been filed, only fifty-five have been granted, eighteen have been finally denied, and seventy-eight have effectively been denied by the agencies' requesting further information that the parties have been unwilling or unable to supply. ${ }^{65}$ Thus only eighteen percent of variance applications to date have been disposed of by the agencies. More significantly, decisions on applications are not made for more than a year after filing: the average time lapse between the initial application date and the granting of a variance is fifteen months, and the comparable figure for those applications finally denied is fourteen months. ${ }^{66}$

62. Id. See also ERISA Procedure 75-1, supra note 58.

63. Memo of Understanding, supra note 56.

64. Id. See ERISA $\S 408(a), 29$ U.S.C. $\$ 1108(a)$ (Supp. V 1975).

65. Case Analyst Interview, supra note 61 (figures apply to period ending Nov. 28, 1977). This information is available at the Public Documents Room of Pension and Welfare Benefit Programs, Room N-4677, U.S. Dep't of Labor, 200 Constitution Avenue, N.W., Washington, D.C.

66. The time lapse for all variances granted as of November 28,1977 , is as follows (where class exemptions involve more than one application, time lapse is based on first application filed, which is listed first in parentheticals below): PTE (class) 75-1, 40 Fed. Reg. 50,845 (1975) (Application No. n.a.; 11 months); PTE (class) 76-1, 41 Fed. Reg. 12,740 (1976) (Application No. n.a.; 15 months); PTE 76-2, 41 Fed. Reg. 16,642 (1976) (Application No. n.a; 11 months); PTE 76-3, 41 Fed. Reg. 26,291 (1976) (Application No. L-308; 9 months); PTE 76-4, 41 Fed. Reg. 29,502 (1976) (Application No. L-313; 9 months); PTE 76-5, 41 Fed. Reg. 30,414 (1976) (Application No. L-262; 12 months); PTE 76-6, 41 Fed. Reg. 46,799 (1976) (Application No. D-237; 15 months); PTE 76-7, 41 Fed. Reg. 48,200 (1976) (Application No. D-417; 8 months); PTE 76-8, 4 I Fed. Reg. 50,518 (1976) (Application No. L-307; 25 months); PTE 76-9, 41 Fed. Reg. 53,219 (1976) (Application No. D.158; 13 months); PTE 76-10, 41 Fed. Reg. 54,080 (1976) (Application No. D-333; 12 months); PTE 76-11, 41 Fed. Reg. 54,037 (1976) (Application No. L-502; 8 months); PTE 77-1, 42 Fed. Reg. 13,633 (1977) (Application No. L-406; I4 months); PTE 77-2, 42 Fed. Reg. 13,633 (1977) (Application No. L-341; 12 months); PTE (class) 77-3, 42 Fed. Reg. 18,734 (1977) 
The effect of this long delay in agency action is that, even if a variance is granted, it may come too late to be of any value. Many variance requests involve short-range transactions, such as temporary leases and short-term loans. ${ }^{67}$ An example is the case of a union plan that desired to borrow money from the union in order to meet the monthly premium payments to its health insurance carrier for the period between August 1975 and May $1976 .{ }^{88}$ The plan filed a variance application in August 1975, but the exemption was not granted until July $1976 .{ }^{69}$

Delays in agency action result not only in the effective denial of some variance requests but, even more importantly, may prevent the filing of many other deserving applications. ${ }^{70}$ Small plans are probably deterred from seeking variances at all; their short-range transactions might not be worth the year's wait. Furthermore, larger transactions involving more substantial plans may be stifled because such deals often depend on quick action. For example, in a recent financing deal, the pension fund of a large corporation had the opportunity to underwrite a line of credit offered by a bank to the corporation. ${ }^{71}$ Although

(Application No. D-025; 23 months); PTE (class) 77-4, 42 Fed. Reg. 18,732 (1977) (Application No. D-055; 24 months); PTE 77-5, 42 Fed. Reg. 22,057 (1977) (Application Nos. D-150, 381; 16 months); PTE 77-6, 42 Fed. Reg. 23,217 (1977) (Application No. L-317; 18 months); PTE (class) 77-7, 42 Fed. Reg. 31,575 (1977) (Application Nos. D-157, 167, 179, 212, 219, $254,281,285,286,337,338,357,388,398,403,413,425,429,438,514,518,540,552,564$, 565, 588, 589, 591; 21 months); PTE (class) 77-8, 42 Fed. Reg. 31,574 (1977) (Application Nos. same as in PTE 77-7; 21 months); PTE (class) 77-9, 42 Fed. Reg. 32,395 (1977) (Application Nos. D-183, 301, 419, 459, 466, 573; 24 months); PTE (class) 77-10, 42 Fed. Reg. 33,918 (1977) (Application No. L-562; 8 months); PTE 77-11, 42 Fed. Reg. 45,425 (1977) (Application No. D-850; 14 months).

The time lapse for all final denials issued as of November 28, 1977, is as follows: Application Nos. D-032 (23 months); D-160 (18 months); D-166 (18 months); D-184 (17 months); D-190 (20 months); D-198 (17 months); D-247 (15 months); D-257 (15 months); D-273 (14 months); D-348 (I3 months); D-369 (18 months); D-387 (11 months); D-457 (12 months); D-465 (6 months); D-497 (9 months); D-609 (8 months); D-695 (8 months); L-275 (15 months).

67. See 41 Fed. Reg. 55,245 (1976) (notice of pendency of exemption for plan that desired to lease equipment on short-term basis from contributing employer; plan not sufficiently capitalized to purchase equipment and no other short-term lease available); id. at 15,481 (notice of pendency of exemption for plan to get short-term loan from sponsoring union to pay health insurance premiums).

68. General Oversight Hearings, supra note 49 , at 48 .

69. PTE 76-5, 41 Fed. Reg. 30,414 (1976).

70. The Rules interfere with short-term business arrangements. See note 67 supra. The realities of the business world preclude parties from waiting a year for a determination as to whether a particular transaction is permitted. For example, the six classes of prohibited transactions described in Weiss \& Voboril, supra note 38 , in most cases could not be carried out if the parties were required to wait a year or more for the imprimatur of a governmental agency. One might infer that many meritorious variance applications are never filed, because there is an inherent conflict between the businessman's need for prompt action and the agencies' lengthy decisional process.

71. Interview with New York pension lawyer. Nov. 4, 1977 (notes on file with Yale Law Journal). 
the interest rate was higher than that available from investments of comparable risk and the plan's trustee could withdraw the plan's funds at any time, the plan could not take advantage of this profitable investment opportunity because it was a prohibited transaction. Counsel advised against applying for a variance, since the money was needed quickly and variance procedures took too long. Indeed, the general policy of counsel, a major New York law firm, is to forgo or restructure a transaction rather than to apply for a variance. ${ }^{72}$

The agencies' inability to process variance applications in a timely manner has prompted the House subcommittee charged with oversight of ERISA" to express concern that "the administrative burden on the agency may well exceed its capabilities, if it seeks to effect the congressional intent and exempt those innocent transactions." ${ }^{4}$ This dissatisfaction, together with the poor record of the agencies in processing variance requests, indicates the need for re-evaluation of current decisionmaking. At present, there are two main reasons for agency delay: an overprotective, complex standard for granting variances and lengthy, duplicative procedures.

\section{An Overprotective and Complex Standard}

The Act provides that the agencies exempt "innocent transactions" that are "protective of the rights" and "in the interests" of plan participants. ${ }^{76}$ Application of this standard contributes to delays because it requires an extensive and complex evidentiary examination. ${ }^{77}$

72. Id. An interview with a second New York pension lawyer (Nov. 4, 1977) revealed another example of a deserving variance application that was never filed (notes on file with Yale Law Journal). In this case, the Rules prevented the typical structuring of a lease financing in which a corporation sets up a "dummy" company to borrow money to finance a project. In the past, the corporation's investment banker would own the "dummy," but this arrangement was prohibited under the Rules. As a result, the corporation was forced to pay a disinterested third party to own the "dummy" even though there was no danger or possibility of abuse in such ownership. A variance application was not filed because of the "inordinate length" of the response time.

73. See House Amendment Report, supra note 52, at 1 (Subcomm. on Labor Standards of the House Comm. on Education and Labor).

74. Id. at 6.

75. "Innocent transactions" are those where adequate safeguards against fiduciary abuse are present. See CONFERENCE REPORT, supra note 31, at 5089-90.

76. See ERISA \$ 408(a), 29 U.S.C. $\$ 1108$ (a) (Supp. V 1975). The third criterion, that the variance be "administratively feasible," see p. 771 supra, appears to have no content; not a single grant or denial of a variance request was at all affected by this meaningless phrase. See Applications, supra note 66.

77. For example, see PTE 76-7, 41 Fed. Reg. 48,200 (1976), and notice of this exemption, 41 Fed. Reg. 20,455 (1976) (involving five-year-old loan agreement between plan and sponsoring corporation complicated by sale of assets of sponsor to another corporation; sponsor renewed loan by giving security interest in property to plan; plan then attempted 
Congress suggested that the agencies investigate "the nature and purpose of the plan, and the indispensability of the proscribed transaction to effectively carrying out the purposes of the plan, [and] the extent to which participants under the plan possess alternative methods of investing or managing their accounts." 78 In practice, determination of whether the variance will be "in the interests" of plan participants often results in agency consideration of a great volume of intricate market and financial information, including whether substitutes are available in the market and whether the party-in-interest and the plan will suffer "economic loss" if the exemption is denied. ${ }^{79}$

The vagueness of the statutory criteria, moreover, compounds the problem of delay unnecessarily. The Act establishes the three criteria as guides for decisionmaking, but offers no definition of them. The criteria are not self-defining and, indeed, seem to overlap in meaning; yet the agencies have neither elaborated nor followed any guidelines, except to indicate that an application must comply with the "statutory criteria." 80 In practice, most crucial is the "in the interests" criterion, which often requires the balancing of conflicting factors ${ }^{81}$ in a wholly undefined way. This has engendered uncertainty and may lead to arbitrary results. ${ }^{82}$ Moreover, it is not clear that the information re-

to enjoin sale of sponsor's assets); PTE 77-5, 42 Fed. Reg. 22,057 (1977), and notice of this exemption, 41 Fed. Reg. 55,664 (1976) (exchange of assets between plan and interested parties; incomprehensible fact situation covers several pages of Federal Register).

78. SenAte RePort, supra note 2, at 4869.

79. See ERISA Procedure 75-1, supra note 58.

80. See application files on grants and denials of variances, supra note 66; Case Analyst Interview, supra note 61.

81. The variance decisional process involves a consideration of the "economic loss" or "hardship" to the party-in-interest, usually the plan sponsor, seeking a variance and of whether a notice of termination has been filed with the Pension Benefit Guarantee Corporation. ERISA Procedure 75-1, supra note 58; Case Analyst Interview, supra note 61. Consideration of these factors is not directly relevant to whether a variance is "protective of the rights" and "in the interests" of plan participants but, rather, affects participants only to the extent that costs to the sponsor deter his commitment to the plan. See p. 769 \& note 50 . That these decisions might require a balancing of direct and indirect costs to plans was acknowledged by Congress. Joint Oversight Hearings, supra note $\mathbf{5 0}$, at 2 (effort must be made to "balance these competing concerns"-objectives of pension reform and encouragement of growth and continuation of both small and large employee benefit plans).

82. Interview, supra note 71 (at present, it is impossible to predict accurately the outcome of any Department decision on a variance request). The need for specific, meaningful standards to control agency discretion is recognized. See K. Davis, Discretionary JUSTICE 55 (1969) ("When legislative bodies delegate discretionary power without meaningful standards, administrators should develop standards at the earliest feasible time ....")

The arbitrariness of current agency action is illustrated by the different outcomes on two similar variance applications. Application No. $\mathbf{D - 4 6 5}$, Apr. 6, 1976, was filed by a plan that wished to purchase and lease equipment to the employer. The employer proposed to maintain a compensating balance, and the plan was to receive an annual return 
quired to satisfy the "in the interests" standard is always useful. To be sure, the detailed factual investigation required by this standard will detect latent opportunities for abuse; but, on balance, such investigation probably defeats or delays many worthy applications.

\section{Lengthy and Duplicative Procedures}

The delays that inhere in determining whether a transaction is "in the interests" of plan participants are exacerbated by the complicated process of disposing of variance applications. In particular, the dual jurisdiction of the Labor Department and the IRS-placing "joint and co-equal authority in two cabinet agencies with differing institutional perspectives, expertise, and responsibilities" 83 -results in duplicative procedures. An initial time lag occurs when the agencies determine primary and secondary responsibility for individual applications. After the agency with primary responsibility has made its investigation and reached a tentative decision, the secondary agency undertakes a separate investigation and reaches an independent decision. ${ }^{84}$ If the two agencies agree to grant a variance, notice, comment, and possibly a hearing follow. Where the Rules' self-dealing provisions are involved, a hearing is required and no doubt produces several months' delay ${ }^{85}$

\section{Toward Workable Administrative Exemptions}

Congress has expressed dissatisfaction with the operation of the administrative variances, and reforms have been proposed. One such proposal calls for the creation of a single federal agency that would have sole responsibility for the administration of all provisions of the Act. ${ }^{86}$ Although a single agency would eliminate the.current problem of dual jurisdiction, the proposal does not address the more important

in excess of $10 \%$. Further, the lease would only be submitted to the plan if the terms were accepted by two independent leasing firms. This request for a variance was denied; the Department of Labor claimed that there was "no showing made that the Plan will receive a return on its investment greater than could be provided on investments with partics independent of the Employer." Nevertheless, in Application No. D-161, see [1976] 3 PENSION \& Profit Sharing (P-H) ff 135,356, the Department has proposed that a variance be granted for a similar "leaseback" arrangement between a plan and an employer where no showing was made that the terms of the transaction were "greater" than could be obtained from a disinterested party.

83. [1976] 1 Pension \& Profit Sharing (P-H) ๆ 4.10 (quoting testimony of former Labor Department Administrator William Chadwick).

84. See Memo of Understanding, supra note 56.

85. ERISA § 408(a), 29 U.S.C. $§ 1108$ (a) (Supp. V 1975). The scheduling, notice, and processing involved in a full evidentiary hearing adds several months to the variance review process.

86. H.R. 4340, 95th Cong., 2d Sess., 123 Cong. Rec. HI661 (daily ed. Mar. 2, 1977) (Rep. Dent) (H.R. 4340 would merge administrative and enforcement functions of IRS and Dep't of Labor into single "Employee Benefits Administration"). 
issue-the lack of an easy-to-administer standard. Another proposal calls for the repeal of the party-in-interest sections of the Prohibited Transactions Rules. ${ }^{87}$ This change would sacrifice the advantages of prophylactic protections against fiduciary abuse and would perpetuate the basic deficiencies in the variance procedures of the self-dealing provisions of the Rules. ${ }^{88}$ Although these suggested reforms are inadequate, they do point to the two main avenues for constructive change: narrowing the reach of the Rules and streamlining procedures in order to minimize delay and other costs incurred by plans seeking variances.

\section{A. Establishing an "Objective Fairness" Standard}

The reform most essential for expediting the variance process is the establishment of a decisional standard that is easy to apply and consistent with the other fiduciary standards of the Act. This Note suggests an "objective fairness" test, whereby a variance would be granted whenever the applicant demonstrates that the terms of the transaction, from the perspective of the plan, are at least as favorable as the terms that would be reached by parties in an "arm's length" bargain. This test is derived from the standards for fiduciary conduct found in ERISA and the common law. Section 404's mandate that the fiduciary act as a prudent financial expert for the exclusive purpose of benefiting the plan is consonant with the proposed test. ${ }^{89}$ Furthermore, the statutory exemptions and the transitional rules recognize that certain prohibited transactions should be allowed if the plan receives at least marketplace terms. ${ }^{90} \mathrm{~A}$ standard analogous to this objective fairness criterion governs general corporate law cases: an adequate defense for corporate fiduciaries in a position of conflict of interest has always been that the deal was arrived at by arm's length bargaining and reflects fair consideration. ${ }^{91}$

87. See House Amendment Rerort, supra note 52, at 4-6, 28-29 (report on H.R. 7597 calling for repeal of party-in-interest provisions of Prohibited Transactions Rules).

88. But see Gerard \& Schreiber, supra note 49, at 389 (H.R. 7597 would remedy many problems and reduce need for cumbersome administrative action).

89. ERISA $\S 404,29$ U.S.C. $\$ 1104$ (Supp. V 1975). The test would only allow transactions that involve fair market values and other "arm's length" terms; that is, the test would only allow behavior expected of a "prudent man." See pp. 765-66 \& note 30 supra.

90. ERISA $\$ 414(c)(3), 29$ U.S.C. $\$ 1114(c)(3)$ (Supp. V 1975) (Rules shall not apply until 1984 to any sale or other disposition of property between plan and party-in-interest if amount reccived by plan is "not less than fair market value"); $i d . \$ 408(\mathrm{~b}), 29$ U.S.C. $\$ 1108$ (b) (Supp. $V$ 1975) (each statutory exemption contains requirement that plan receive reasonable interest rate, adequate consideration, or like).

91. See W. Cary, Cases and Materials on CoRporations 565-66 (4th ed. 1969) (majority of jurisdictions now holds that transaction involving interested director is voidable only if "unfair ... or if the directors acted in bad faith"). 


\section{Ease of Application}

The proposed standard would substantially expedite decisionmaking by requiring a less complex factual inquiry than that currently undertaken. Under the present statutory criteria, in determining whether the variance will be "protective of the rights" of plan participants, the agencies consider objective evidence of the marketplace fairness of the transaction. This often involves an appraisal by independent experts and presentation of evidence of current market values. ${ }^{02}$ Such evidence is usually available to parties seeking variances and, more importantly, is fairly easy for the agency to check for veracity. The objective fairness test essentially adopts this first level of analyzing variance applications. The standard goes no further, however, for it merely seeks to guarantee the basic economic rationality of the transaction.

Hence, under the proposed test, the agencies would not delve into the additional level of detail that they now examine under the "in the interests" standard. For example, under the objective fairness test a loan by the plan to a party-in-interest would be scrutinized only to determine that the loan is adequately secured and that the interest rate is reasonable. In contrast, the present standard requires the party to make an extensive evidentiary showing, including a demonstration that the terms "are greater than those offered by unrelated third parties under similar circumstances." 93 This "best terms available" requirement places an inordinate burden on the party seeking a variance insofar as it demands that the applicant establish that the plan cannot obtain better terms somewhere in the marketplace. All that reasonably can be expected of a party is for him to present evidence, in the form of an independent appraisal or the like, that the terms of the transaction reflect "fair market values." This observation is buttressed by certain of the transitional rules and class exemptions, which demand no more than "adequate" or "reasonable" terms, not the "best available terms."

The advantages of adopting the objective fairness test for deciding variance applications are considerable. The major advantage of the test is that it would transform the variance process into a workable

92. See, e.g., PTE 77-1, 42 Fed. Reg. 13,633 (1977); 41 Fed. Reg. 43,976 (1976) (noting pendency of exemption; appraisers recommended purchase price for tract of land between $\$ 250,000$ and $\$ 300,000-$ plan purchase at $\$ 250,000$ falls within recommended range and is reasonable); PTE 77-2, 42 Fed. Reg. 13,633 (1977); 41 Fed. Reg. 56,412, 56,413 (1976) (noting pendency of exemption; land that plan was to purchase from party-in-interest for $\$ 24,859$ was appraised by independent person at \$28,300); PTE 76-4, 41 Fed. Reg. 29,502 (1976); 41 Fed. Reg. 15,482 (1976) (noting pendency of exemption; independent appraisal put fair market value at $\$ 52,500$, thus purchase by plan at $\$ 45,000$ was not abusive).

93. See Application No. D-387, Jan. 12, 1976 (on file with Yale Law Journal). 
safety-valve that would mitigate the costs of the Prohibited Transactions Rules. The test would enable the agencies to process applications without the time-consuming detailed factual investigation required by present statutory standards. The investigation would involve a limited range of information about the market value of the goods or services at stake in the transaction-information that should be accessible to investigators. In addition, the proposed standard is a better defined, more determinate one than the statutory criteria currently employed. As a result, applicants under the new test would be better able to gauge the validity of their petitions and to make plans accordingly.

\section{Adequate Protection Against Fiduciary Abuse}

Besides reducing delays and providing greater clarity, the objective fairness test would result in the approval of many more applications than are currently granted without greatly sacrificing the protection afforded by the present standard. Of the eighteen variance applications denied "on the merits,"94 only two would have been denied pursuant to the proposed test. ${ }^{95}$ The test thus would permit more variances in a shorter time; objection may be raised, however, that it would undermine the goals of the Rules by allowing too many abusive transactions. For example, the proposed standard would permit some loans that benefit the party-in-interest at the expense of the plan, such as a loan at the "going rate" when money is tight and when loans are unavailable at any rate of interest. ${ }^{96}$ It would also allow an employer who has surplus inventory to sell it to the plan at a fair price, even if the plan does not need the goods. On balance, however, the objective fairness test would

94. See Case Analyst Interview, supra note 61 .

95. See note 66 supra (list of all 18 denials). The two variance applications that would have failed the "objective fairness" test are Application No. D-160, June 6, 1975 (on file with Yale Law Journal), and Application No. L-275, Sept. 9, 1975 (on file with Yale Law Journal). Both involved unsecured loans from a plan to a party-in-interest. The lack of adequate security is not commensurate with arm's length bargaining and would have caused the denial of these requests under the proposed test. In applying the "objective fairness" standard to several of the other applications, it may have been required that the parties supply additional information to clarify the arm's length nature of the transaction. See, e.g., Application No. D-166, May 28, 1975 (on file with Yale Law Journal) (Dep't of Labor claimed that party-in-interest failed to prove that terms were arm's length).

96. See S. Rep. No. 552, 91st Cong., 2d Sess. 28-29 (1969), reprinted in [1969] U.S. Cone Conc. \& AD. NEws 2055 (cxamples of three types of abusive transactions that arm's length standards often permit: (1) purchase of property from interested party at fair price when party needs cash and cannot find buyer; (2) loan to interested party with adequate security at reasonable rate of interest when money market tight and party unable to find alternate sources of funds; (3) lease from interested party when latter needs advance leases to secure financing for construction or acquisition of property). 
afford an effective, albeit reduced, level of protection against fiduciary abuse.

First, the objective fairness test would prevent the vast majority of transactions that harm pension plans. Indeed, the proposed scheme retains the major advantage of the Prohibited Transactions Rules: the plan fiduciary has the evidentiary burden of justifying the transaction to a federal agency and may not proceed with the transaction, without risking stiff penalties, until the agency is convinced of the fairness of the terms. This alone should continue to discourage many abusive transactions. Moreover, a determination that the terms of a particular transaction between a plan and party-in-interest are at least as favorable to the plan as those arrived at in an arm's length bargain would prevent the types of abuses that prompted Congress to enact ERISA: unsecured loans at no interest, purchases of worthless stock, and leases of worthless equipment. ${ }^{97}$ The scandals involving pension funds of the Mine Workers, Penn Central, and Teamsters would not have met the objective fairness test. ${ }^{98}$

In cases where the objective fairness test would not prevent certain abusive transactions from receiving administrative exemptions, the Act's other fiduciary responsibility provisions will serve as an effective second level of protection. Whether or not a variance is granted, the stringent fiduciary guarantees of section 404, the "prudent expert" and "exclusive benefit" rules, ${ }^{99}$ are still applicable to fiduciary conduct. ${ }^{100}$ These standards may be enforced against a fiduciary by the Department of Labor or by private actions. ${ }^{101}$ Because the Act's disclosure sections mandate regular plan reports that are available to participants and because participants will receive notice of exemption applications, civil suits may be an effective means of controlling abuse. For example, plan participants might sue for violation of the exclusive benefit rule when a fiduciary purchases unnecessary inventory for the plan.

Of the abuses that would not be prevented by the proposed test, many are also beyond the reach of the existing statutory criteria. Fiduciaries committing the most fraudulent abuses-bribery and embezzlement-may not apply for variances in the first place. Carefully

97. See House Hearings, supra note 12, at 470-72 (statement of George Shultz, Sec'y of Labor). The abusive practices detailed by Mr. Shultz would have been prohibited by the simple requirement that the terms of the transaction be adequate or reasonable.

98. See p. 763 \& notes 15-18 supra. Each of these instances of abuse involved transaction terms that were not commensurate with "arm's length" bargaining.

99. See pp. 765-66 supra.

100. The variance section of the Act provides that any "exemption granted under this section shall not relieve a fiduciary from any other applicable provision of this Act." ERISA $\S 408(a), 29$ U.S.C. $\$ 1108$ (a) (Supp. V 1975).

101. See p. $765 \&$ note 29 supra. 
concealed fraud, including the surplus inventory situation, may circumvent both standards. ${ }^{102}$ Moreover, the objective fairness standard may enable the Labor Department to rely less on "class exemptions" and thus to afford better protection against fiduciary abuse in some situations. Because a class exemption entitles fiduciaries who comply with its terms and conditions to proceed with a particular prohibited transaction without applying for a variance, ${ }^{103}$ participants may be left with a lesser degree of protection, since the advantages of prior review and the applicants' burden of proof are lost. Nevertheless, the agencies are placing increasing reliance on class exemption. ${ }^{104}$ The simplification of the process for review of individual variance applications may result in more widespread use of them; in the long run, this could provide a more effective means of "protecting the rights" of plan beneficiaries.

\section{B. Streamlining Procedures}

To ensure an expeditious decisional process, implementation of an objective fairness test should be accompanied by a streamlining of agency procedures. Congress should give the Department of Labor primary responsibility for administering variances, which would prevent the duplication of efforts and other problems arising from dual jurisdiction. The Labor Department is familiar with the special circumstances and problems surrounding the administration of employee benefit plans. ${ }^{105}$ The role of the Internal Revenue Service should be limited to giving advice to the Department concerning future policy. This change would eliminate the need for the existing preliminary conference designed to determine primary responsibility in individual cases and the review of the entire application by the secondary agency. Since approximately one-half of existing procedures would be eliminated, the processing time for applications might be shortened by as much as fifty percent in some cases.

102. Since the "in the interests" standard involves a more detailed investigation into the specific facts of the transaction, it is not disputed that this standard is a more effective deterrent of such fraudulent transactions.

103. See ERISA $\S 408(\mathrm{~b}), 29$ U.S.C. $\$ 1108$ (b) (Supp. V 1975); CoNFERENCE REPORT, supra note 31 , at 5092-97.

104. In 1976, only one of the 11 administrative variances granted was a class exemption. In 1977 (as of Nov. 28, 1977), six of the 11 variances granted have been class exemptions. See note 66 supra. This Note does not argue that class exemptions should never be relied on in the administrative exemption process. The agencies should recognize, however, that the class exemption offers a different, and often lesser, degree of protection against fiduciary abuse.

105. Cf. Senate Report, supra note 2, at $4852-53$ (Secretary of Labor should be given sufficient power to implement provisions of Act; Secretary already has investigatory powers in enforcing Welfare and Pension Plans Disclosure Act). 
Second, a rigorous timetable should be adopted by the Department of Labor. The Department's goal should be to decide variance applications within two months of submission. ${ }^{106}$ Thus, when a fiduciary applies for a variance, the agency should immediately give notice to affected parties and begin fäctfinding. Further, the present requirement for an evidentiary hearing whenever an application involves the self-dealing prohibitions should be eliminated. The hearing often delays the application for several months and is rarely useful; indeed, interested parties sometimes fail to attend hearings under the present system. ${ }^{107}$ Moreover, the submission of comments should in most cases be sufficient to alert the Department to problematic applications.

The primary advantage of these proposals is their assurance of timely disposition of variance applications. By eliminating agency duplication and unnecessary procedures and by establishing a less complex standard for decisionmaking, the reforms should enable the Department of Labor to process most requests within two months of application. Business planning should be facilitated, because interested parties will be given a fast answer from the Department and should be able to predict with greater confidence the ultimate decision. Applications for short-term or emergency needs might no longer be discouraged, and deserving requests would be granted without costly delays in implementation. In sum, plan managers would no longer be deterred from seeking variances by the existing constraints of administrative delay, unpredictability, and substantive restrictiveness.

As a result of the proposals, plans should benefit financially, at least in part because they will be better able to take advantage of profitable opportunities offered by parties-in-interest. The proposed reforms would ensure expeditious processing of variance applications, and thus would permit profitable transactions that are protective of the interests of plan beneficiaries.

106. This goal appears to be reasonable. Indeed, the Department of Labor has had no problem meeting the 60-day limit on the bringing of suits to overturn union elections under Title IV of the LMRDA, which involves an even more complex and lengthy investigation. LMRDA $\S 402$ (b), 29 U.S.C. $\$ 482$ (b) (1970). See U.S. DEP'T OF LABOR, UNION Election Cases Under the Labor-Management Reporting and Disclosure Act 1966-1970, at 4-6 (1970); [1977] I LAB. REL. REP. (96 News \& Background Info.) 140 (Department of Labor investigation and decision whether to bring suit to overturn national election of Mine Workers reached within 60-day limit); cf. Oversight Hearings on the National Labor Relations Board: Hearings Before the Subcomm. on Labor-Management Relations of the House Comm. on Education and Labor, 94th Cong., 1st Sess. 6.7 (1975) (in 83\% of cases NLRB Regional Director conducts investigation and hearings within 44 days in deciding whether to hold representation election).

107. See PTE 76-10, 41 Fed. Reg. 54,080 (1976) (only one individual requested hearing and he failed to attend). 